\title{
Compost of Yellow Creeping Daisy (Wedelia Trilobata, L.) Weed to Increase Organic Tomato Yield
}

\author{
Nanik Setyowati ${ }^{1}$, Zainal Muktamar ${ }^{2}$, Eka Wiyanti ${ }^{3}$ \\ ${ }^{1}$ Department of Crop Production, Faculty of Agriculture, University of Bengkulu, Indonesia \\ ${ }^{2}$ Department of Soil Science, Faculty of Agriculture, University of Bengkulu, Indonesia \\ ${ }^{3}$ Agroecotechnology Study Program, Faculty of Agriculture, University of Bengkulu, Indonesia
}

\begin{abstract}
Numerous weeds, including Yellow Creeping Daisy (Wedelia trilobata) are sources for compost. Compost efficacy is dependent on several factors, including the source of organic matter, the dosage, the application method, and the period of the application. The purpose of this study was to compare tomato (Lycopersicum esculentum, Mill) growth and yield at various Yellow Creeping Daisy (YCD) compost doses and application times. The experiment employed a completely randomized design (CRD) with a factorial arrangement consisting of two factors. The treatment combinations were repeated three times. The first factor was the timing of compost application, which were two and one weeks prior to planting, and on planting day. The second factor was the dosage of compost, which was $0,10,20$, or 30 tons/Ha. Application of YCD compost 1-2 weeks before tomato planting provided greater yield than at planting, as indicated by number of fruit, fruit diameter, and fruit weight per plant. Higher dose of YCD compost application increased the yield of tomato. Application of the compost 2 weeks before planting at 30 tons/ha resulted in the highest yield of tomato.
\end{abstract}

KEYWORDS: Compost, Lycopersicum Esculentum, Organic, Tomato, Wedelia Trilobata

\section{INTRODUCTION}

Tomatoes (Lycopersicum esculentum Mill) are horticultural crop suitably grown in tropical and sub-tropical climates and on various soil orders, including Andosols, Entosols, Ultisols, and Vertisols. Most soils in Bengkulu Province, Indonesia, are classified as Ultisols. According to [1], the main obstacle of Ultisols is its low soil pH and high exchangeable Al, leading to phosphate fixation. Also, the soil has low nitrogen content. Low content of nitrogen in the soil is associated with a very intensive leaching process at humid tropical climate, resulting in low soil fertility. Therefore, it is necessary to increase the productivity of Ultisols, among others, through soil improvement (amelioration), fertilization, and the addition of organic matter.

In Bengkulu Province, tomatoes are primarily grown in Ultisols. However, the improvement Ultisols fertility is necessary to obtain satisfied yield of tomatoes. Incorporating organic matter of compost into the soil is a way to enhance soil fertility of the soil. Compost is an organic fertilizer made by decomposing the remains of living organisms (plants and animals). Compost can boost the physical and biological properties of the soil and provide nutrients [2]

Compost improves structure (aggregation), Cation Exchange Capacity (CEC), water-holding capacity, and permeability and increases soil organic carbon. The agronomic value of compost is dependent on the quality and quantity of organic matter sources. These traits affect the rate at which organic matter mineralizes in soil, and thus the long-term effects on soil fertility. The slow release of nutrients from compost boosts crop yields in subsequent years [3].

Three months after applying compost Bermudagrass (Cynodon dactylon), the soil organic matter, $\mathrm{C}, \mathrm{P}, \mathrm{Ca}$, and $\mathrm{S}$ content has increased [4]. [5] Concluded that the yield of plants fertilized with Bermudagrass compost at a dose of 36 tons/ha increased by $15 \%$. The application of compost and vermicompost on water spinach increased $\mathrm{pH}$, organic matter, and soil nutrient content higher than synthetic fertilizers [6]. Continuous application of compost increases $\mathrm{N}$ availability even though the $\mathrm{N}$ release process is slow [7]. Organic materials such as plants, animals, and organic waste are sources of compost. Straw, legumes, rice husks, wood chips, twigs, leaves, manure, fruits, and vegetables, and municipal waste are examples of sources of compost [8] [9] [10]. In addition, several types of weeds have the potential as a source of organic fertilizer. Yellow Creeping Daisy (YCD) (Wedelia trilobata L.) has a potential as source of compost [11]. 


\section{International Journal of Current Science Research and Review}

ISSN: 2581-8341

Volume 04 Issue 08 August 2021

DOI: 10.47191/ijcsrr/V4-i8-15, Impact Factor: 5.825

IJCSRR@ 2021

Www.ijcsrr.org

YDC is commonly used as a source an organic fertilizer since the weed rapidly mineralized. Soil organic content, moisture content, and soil $\mathrm{pH}$ increased as soil fertilized with YCD bokashi [12]. Study by [13] conformed that the application of YCD and Siam weed (Chromolaena odorata) compost could substitute nitrogen fertilizer in chili cultivation [13]. YCD compost increased leaf length, the number of leaves, and the leaf area index of mustard plants [14]. YCD is a compost source in sustainable agriculture to reduce or even eliminate synthetic fertilizers in agricultural production. This study aimed to compare tomato (Lycopersicum esculentum, Mill) growth and yield at different doses and application times of YCD compost.

\section{MATERIALS AND METHODS}

\section{Location and Time}

The research was conducted at the Screen House located in Pasar Melintang Village, Teluk Segara Sub District, Bengkulu City, Indonesia, at an altitude of 14 meters above sea level. The experiment used a completely randomized design (CRD) arranged in a factorial, consisting two factors with three replications. The first factor was the time of compost application, i.e., two weeks before planting (WBP), one WBP, and at the planting date. The second factor was the dosage of YCD compost consisting of $0,10,20$, and 30 tons/ha.

\section{Composting Process}

YCD weeds were chopped into $3-5 \mathrm{~cm}$ and weighed $150 \mathrm{~kg}$. YCD is from non-generative plants. Separately, $10 \mathrm{~mL}$ EM-4 solution was dissolved in $1 \mathrm{~L}$ water and then blended with $45 \mathrm{~g}$ sugar. The EM-4 solution was then sprayed into the YCD chopped using a Knapsack sprayer until it was moist. The moistened compost material was then piled up on dry tiles and covered with transparent plastic. The compost pile was turned over once a week for four weeks. The dark color of ripe compost indicated that it was ready for the application.

\section{Growing media}

As planting media, Ultisols was compositely collected at the depth of 0-20 cm. Soil sample was air-dried and sieved with $2 \mathrm{~mm}$ screen and homogeneously incorporated. Each polybag contained $10 \mathrm{~kg}$ of soil and Yellow Creeping Daisy compost according to treatment. The mixture was homogeneously incorporated. The application of YCD was applied $2 \mathrm{WBP}, 1 \mathrm{WBP}$ and at planting at a dose of $0,10,20$, and 30 tons/ha, respectively. The mixture was maintained moist throughout the course of the study by watering when necessary.

\section{Planting}

Tomato seeds were sown at one month old and had had three to four leaves. Each polybag constituted one seedling and was randomly placed $20 \mathrm{~cm}$ apart according to the research design.

\section{Observed variables}

The variables observed included plant height $(\mathrm{cm})$, number of branches, number of fruit/plant, fruit weight/plant $(\mathrm{kg})$, fruit diameter $(\mathrm{cm})$, fruit hardness, and total sugar content ( $\left.{ }^{\circ} \mathrm{brix}\right)$.

\section{Data analysis}

The data were statistically analyzed using analysis of variance (ANOVA) at a 5\% level of significance. Duncan's Multiple Range Test (DMRT) was employed to separate the application time treatment. The orthogonal polynomial at the $5 \%$ was assigned for separating the compost dose treatment and interactions between treatments.

\section{RESULTS AND DISCUSSION}

YCD compost application at different times significantly affected all observed variables except plant height and fruit diameter. All of the variables were significantly affected by differences in compost dosage. On the variables number of branches, the number of fruit/plant, fruit weight/plant, fruit diameter, and fruit sugar content, there was an interaction between application time and YCD compost dose (Table 1). 


\section{International Journal of Current Science Research and Review}

ISSN: 2581-8341

Volume 04 Issue 08 August 2021

DOI: 10.47191/ijesrr/V4-i8-15, Impact Factor: 5.825

IJCSRR@ 2021

www.ijesrr.org

Table 1. Summary of analysis of variance

\begin{tabular}{llll}
\hline Variables & Application time & Dose & Interaction \\
\hline Plant height & $0,20^{\mathrm{ns}}$ & $3,13^{*}$ & $1,89^{\mathrm{ns}}$ \\
Branch number & $5,74^{* *}$ & $10,00^{* *}$ & $3,37^{*}$ \\
Fruit number & $4,44^{*}$ & $10,16^{* *}$ & $3,10^{*}$ \\
Fruit weight & $6,27^{* *}$ & $10,72^{* *}$ & $7,14^{* *}$ \\
Fruit diameter & $0,05^{\mathrm{ns}}$ & $8,77^{* *}$ & $4,79^{*}$ \\
Fruit hardness & $10,69^{* *}$ & $3,80^{*}$ & $1,61^{\mathrm{ns}}$ \\
Sugar content & $5,99^{* *}$ & $3,23^{*}$ & $7,48^{* *}$ \\
\hline
\end{tabular}

Note: $\mathrm{ns}=$ not significantly different, $*=$ significantly different, $* *=$ highly significantly different

The application time of YCD compost did not affect plant height since low availability of nutrients from compost at early stage of plant growth. Compost is slow-release, which means that the nutrients required for plants, particularly nitrogen (N), has not been available in sufficient quantities to support plant growth. In addition to water, plants require protein as one of their building blocks. Nitrogen is necessary for protein production and plants require a large amount of nitrogen during their vegetative period to maintain their growth, including plant height.

\section{Effect of Compost Application Time on Tomato Plant Growth and Yield}

The effect of compost application time on tomato plant growth and yield, fruit hardness and sugar content is shown in Table 2 .

Table 2. Effect of compost application time on plant growth and yield.

\begin{tabular}{crcccccc}
\hline \multirow{2}{*}{ Application time } & \multicolumn{7}{c}{ Variable } \\
\cline { 2 - 7 } & PH $(\mathrm{cm})$ & BN & FN & FD $(\mathrm{cm})$ & FW $(\mathrm{g})$ & FH $(\mathrm{mm} / \mathrm{g} / 5 \mathrm{~s})$ & $\mathrm{SC}\left({ }^{0} \mathrm{brix}\right)$ \\
\hline $\mathrm{P}_{1}$ & 71,91 & $13,75^{\mathrm{b}}$ & $9,00^{\mathrm{a}}$ & 3,35 & $210^{\mathrm{a}}$ & $4,06^{\mathrm{b}}$ & $3,27^{\mathrm{a}}$ \\
$\mathrm{P}_{2}$ & 71,25 & $13,25^{\mathrm{b}}$ & $9,33^{\mathrm{a}}$ & 3,33 & $180^{\mathrm{a}}$ & $4,27^{\mathrm{a}}$ & $3,20^{\mathrm{a}}$ \\
$\mathrm{P}_{3}$ & 69,16 & $14,91^{\mathrm{a}}$ & $6,41^{\mathrm{b}}$ & 3,33 & $90^{\mathrm{b}}$ & $4,37^{\mathrm{a}}$ & $3,13^{\mathrm{b}}$ \\
\hline
\end{tabular}

Note: numbers followed by the same letters at the same column are not significantly different at DMRT $(5 \%) . \mathrm{P}_{1}=2$ weeks before planting; $\mathrm{P}_{2}=1$ weeks before planting; $\mathrm{P}_{3}=$ at planting date; $\mathrm{PH}=$ plant height, $\mathrm{BN}$ : branch number, FN: fruit number, FD: fruit diameter, FW: fruit weight, FH: fruit hardness, SC: sugar content.

Although the difference in compost application time had no significant effect on plant height or fruit diameter, compost applied before planting resulted in a higher number of fruits, a greater weight of fruits, and higher sugar content in the fruits than compost applied at planting (Table 2).

Effect of Compost Dosage on Plant Growth and Yield.

The improvement of the soil physical and chemical properties due to increasing compost dose, followed by a linear increase in plant height (Figure 1). YCD compost applied at a rate of 20 tons/Ha produced taller plants than at dose of 10 tons/Ha and control (unfertilized). There was no significant difference in plant height between the treatments doses of 20 tons/Ha and 30 tons/Ha.

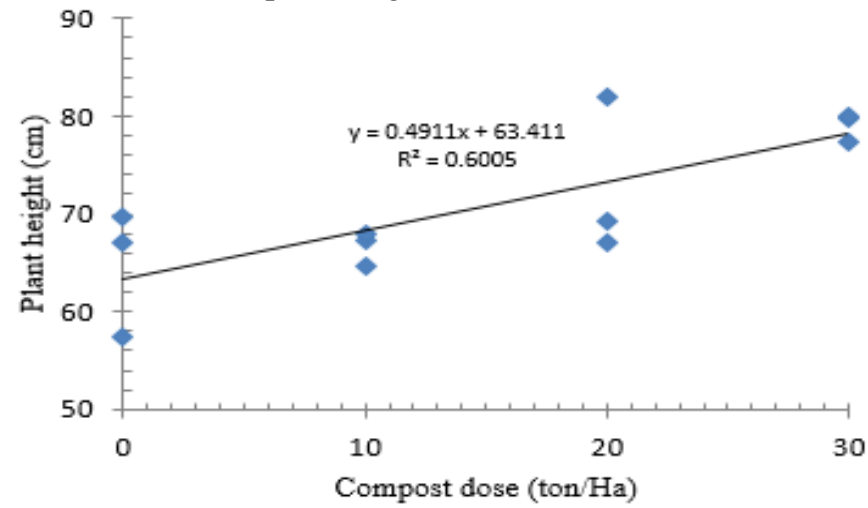

Figure 1. Relationship between plant height and compost dose. 


\section{International Journal of Current Science Research and Review}

ISSN: 2581-8341

\section{Volume 04 Issue 08 August 2021}

DOI: 10.47191/ijcsrr/V4-i8-15, Impact Factor: 5.825

IJCSRR @ 2021

WWw.ijcsrr.org

The tallest plant was resulted in medium fertilized with compost at the dose of 30 tons/Ha $(79 \mathrm{~cm})$, followed by 20 tons/Ha $(72.77 \mathrm{~cm}), 10$ tons/Ha $(66.66 \mathrm{~cm})$, and the lowest at 0 tons $/ \mathrm{Ha}(64.66 \mathrm{~cm})$. These findings suggest that YCD compost provides more nutrients to plants at a 20 - 30 tons'/Ha dose. As [15] points out, plants that have met their nutrient requirements will grow upwards and become taller over time. According to [16], plant height differences are dependent on genetic and environmental factors such as light intensity, temperature, and nutrient availability. [17] concluded that the time of application of Azolla compost, 2 WAT, resulted in greater plant height, the number of leaves, leaf area per plant, and total dry weight of rice than at planting date. The application time of Azolla compost is related to the amount of nitrogen required for the vegetative growth of rice. Figure 2 illustrates the effect of application time and compost dose on the number of branches.

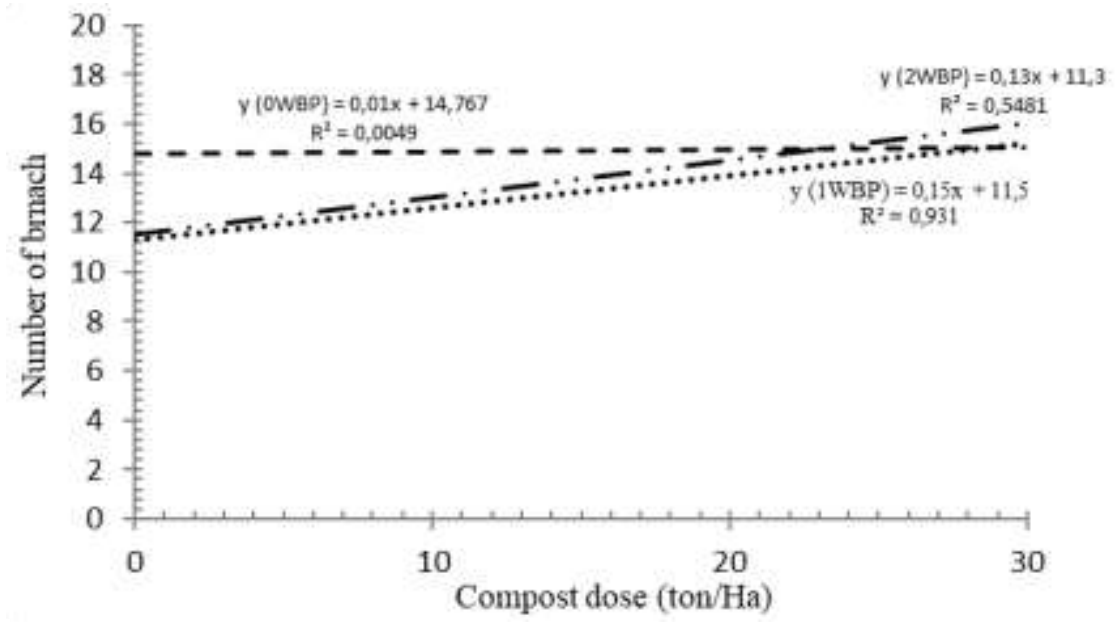

Figure 2. The interaction of application time and compost dose on the number of branches

The highest number of branches, namely 16 fruits, resulted from a 30 tons/Ha compost treatment applied two weeks before planting. The number of branches on each plant is one of the variables that affect the amount of fruit produced by each plant. The higher the number of branches on one plant, the higher the plant's chances to produce fruits [18].

Figure 3 shows the effect of application time and compost dose on the number of fruits/plants. Application of compost one week before planting provided an increase in the number of fruits as the compost dosage increased to 23 tons/Ha. Compost applied at planting time resulted in the lowest fruit weight. The best time for compost application is 2 WBP. Compost applied 2 WBP increased the number of fruits by increasing up to 30 tons/Ha compost doses. The nutrients provided by compost applied $2 \mathrm{WBP}$ were superior to other treatments. Plants use nutrients optimally before entering the generative phase. Compost is a slow-release nutrient source for the soil.

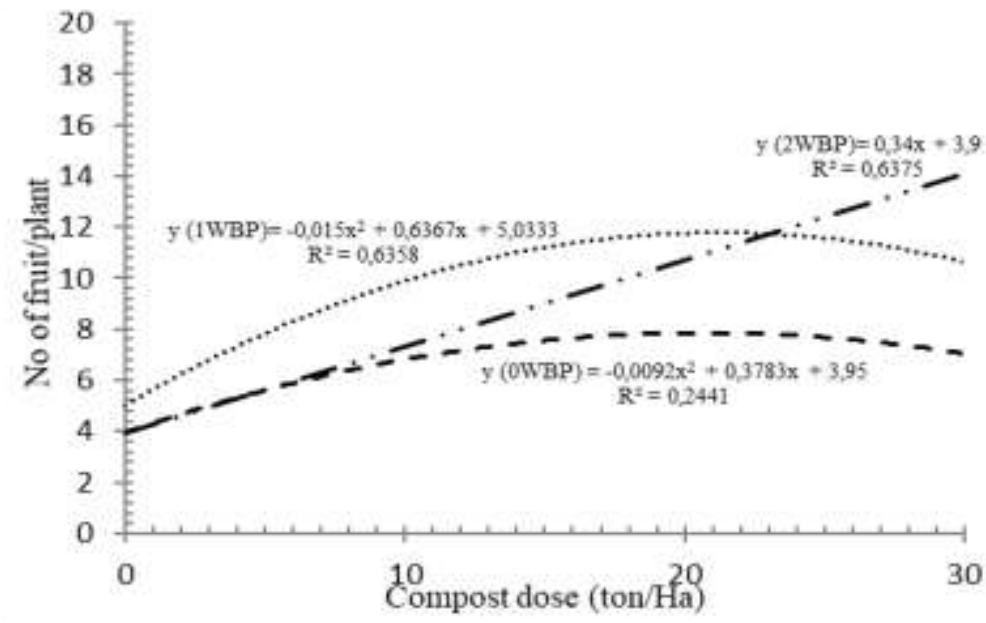

Figure 3. Interaction of application time and compost dose on the number of fruits 


\section{International Journal of Current Science Research and Review}

ISSN: 2581-8341

Volume 04 Issue 08 August 2021

DOI: 10.47191/ijcsrr/V4-i8-15, Impact Factor: 5.825

IJCSRR@ 2021

Www.ijcsrr.org

The best time to apply compost and dose was $1 \mathrm{WBP}$ at $21.22 \mathrm{tons} / \mathrm{Ha}$, which resulted in 13 fruits/plant. This study also revealed that the number of fruits increased with increasing compost doses at 2 WBP (Figure 3). It assumed that an increase in $\mathrm{P}_{2} \mathrm{O}_{5}$ in the soil is responsible for increasing the number of fruits. Compost applied at 2 and $1 \mathrm{WBP}$ provided higher nutrients than compost applied at planting date due to available more time for compost to decompose. As a result, plant roots can absorb the early nutrients available in the soil for plant growth and yield performance. According to [19], mineralization of organic matter will increase plant nutrients and soil carbon followed by an increase in the content of humic and fulvic acids, thereby increasing available $\mathrm{P}$ in acid soil such as Ultisols. Phosphorous is necessary for the formation of flowers and reproductive organs for plants. Figure 4 illustrates the effect of application time and compost dose on fruit diameter.

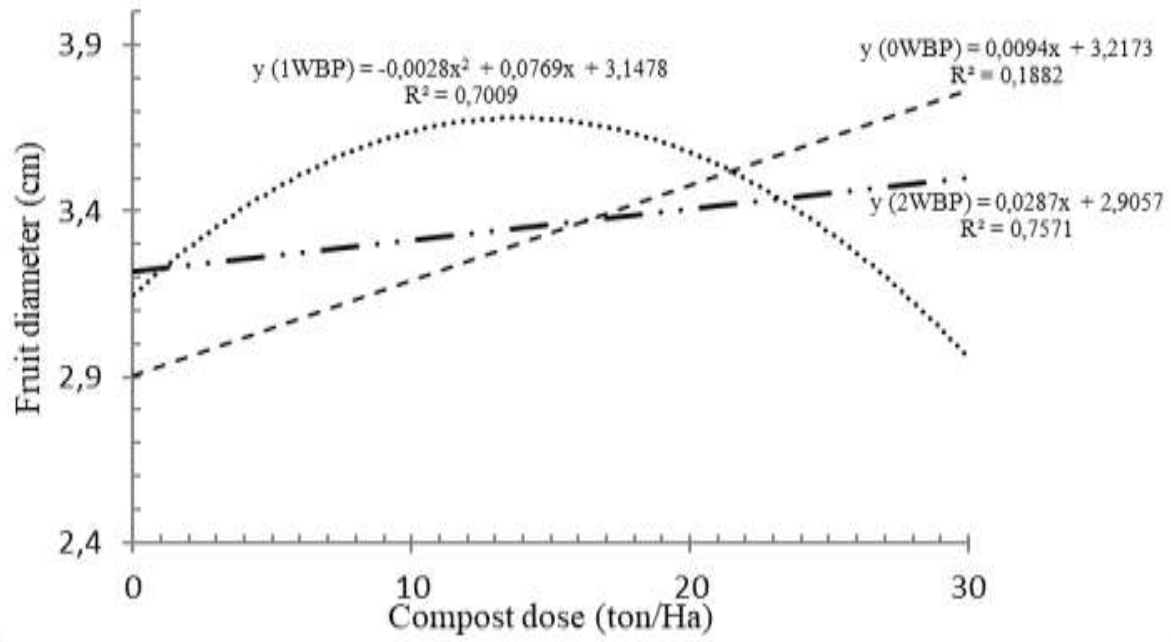

Figure 4. Interaction of application time and compost dose on fruit diameter

The study revealed that $1 \mathrm{WBP}$ at a dose of 13.73 tons/Ha produced fruit with the largest diameter of $3.75 \mathrm{~cm}$ as shown in Figure 4. Also, Figure 5 shows that the optimum compost application time and dose for fruit weight/plant were $1 \mathrm{WBP}$ at a dose of 15.95 tons $/ \mathrm{Ha}$, resulting in the highest fruit weight of $0.38 \mathrm{~kg}$.

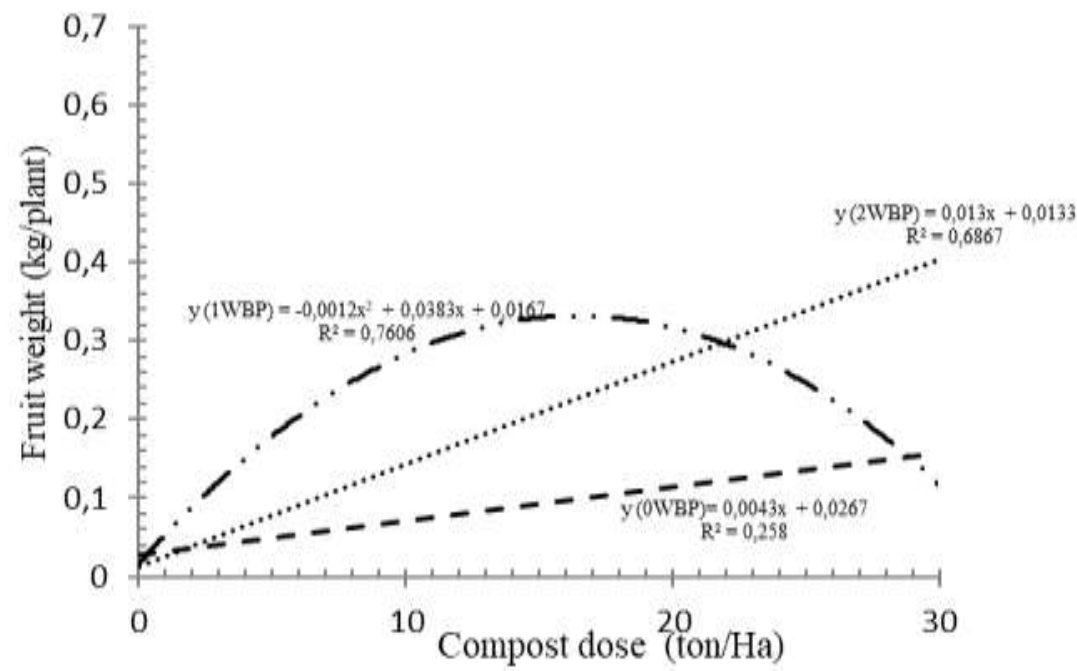

Figure 5. Interaction of application time and compost dose on fruit weight

Compost applied at rates ranging from 23 to 30 tons/Ha reduced fruit weight. The lowest fruit weight was achieved when compost applied at the time of planting. The most appropriate time for compost application is $2 \mathrm{WBP}$ because fruit weight continues 


\section{International Journal of Current Science Research and Review}

ISSN: 2581-8341

Volume 04 Issue 08 August 2021

DOI: 10.47191/ijcsrr/V4-i8-15, Impact Factor: 5.825

IJCSRR@ 2021

Www.ijcsrr.org

to increase at a compost dose of 23 tons/Ha to 30 tons/Ha. This is most likely since compost needs times to decompose in the soil before nutrients are available to plants. As a result, when plants enter the generative phase, nutrients are available for fruit formation.

One of the main goals in farming practice is to achieve a high fruit weight/plant because the higher the fruit weight/plant, the higher the plant productivity. However, producing a large number of fruits/plants is required to produce a considerable fruit weight. The results of this study indicated that as the number of fruits/plants increased, the fruits weight/plants increased as well (Figures 3 and 5). This increase in fruit weight is associated with an increase in soil $\mathrm{P}$ from compost decomposition as required by plant. According to [20], there is a correlation between plant vegetative growth and yield. The vegetative organs involved in assimilation (source) contribute to the user's organs (sink). Plant produces higher fruit will followed by heavier the fruit [21]. According to [22], as the number and diameter of fruits increased, the weight of the chili fruit/plant increased as well.

Figure 6 illustrates the effect of application time and compost dose on fruit sugar content.

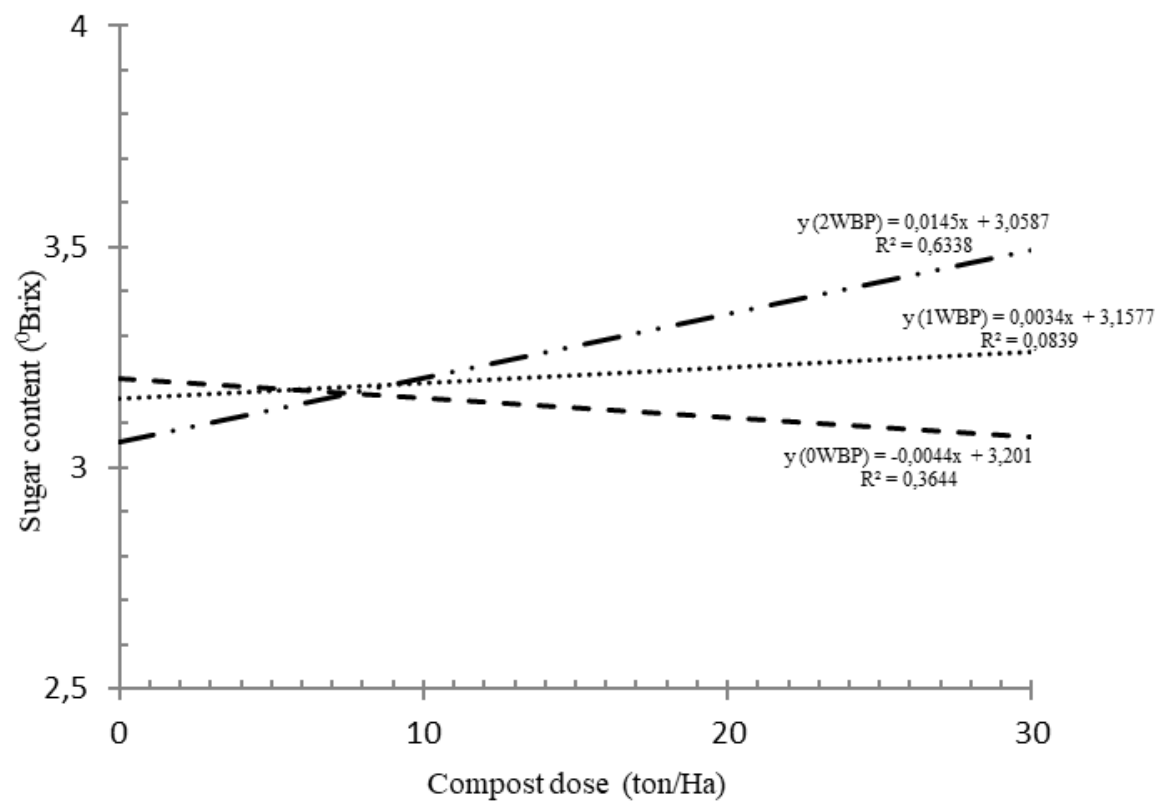

Figure 6. Interaction of application time and compost dose on fruit sugar content.

The study also revealed that the interaction between compost dose and application time resulted in a positive linear relationship on fruit sugar content (Figure 6). Compost applied 2 WBP at a 30 tons/Ha resulted in the highest fruit sugar content of 3.50 bricks. Fruit sugar content will increase as the fruit ripens and decrease as the fruit is stored [23]. This study indicates the earlier compost is applied, the faster the nutrients required to increase sugar content are available.

\section{Relationship between Growth Variables and Crop Yield}

Tomato plant growth and yield variables are correlated, as shown in Table 3.

Table 3. Correlation of Plant Growth and Yield Variables.

\begin{tabular}{|c|c|c|c|c|c|c|c|}
\hline \multicolumn{8}{|l|}{ Correlation } \\
\hline & $\begin{array}{l}\text { Plant } \\
\text { height }\end{array}$ & Branch & $\begin{array}{l}\text { Fruit } \\
\text { number }\end{array}$ & $\begin{array}{l}\text { Fruit } \\
\text { weight }\end{array}$ & $\begin{array}{l}\text { Fruit } \\
\text { hardness }\end{array}$ & $\begin{array}{l}\text { Sugar } \\
\text { content }\end{array}$ & $\begin{array}{l}\text { Fruit } \\
\text { diameter }\end{array}$ \\
\hline Plant height & 1 & $0,60 * *$ & $0,53 * *$ & $0,51 * *$ & 0,07 & 0,21 & 0,19 \\
\hline Branch & $0,60 * *$ & 1 & $0,49 * *$ & $0,42 * *$ & $0,36^{*}$ & 0,29 & 0,17 \\
\hline Fruit number & $0,53 * *$ & $0,49 * *$ & 1 & $0,90 * *$ & 0,15 & $0,51 * *$ & 0,25 \\
\hline Fruit weight & $0,51 * *$ & $0,42 * *$ & $0,90 * *$ & 1 & 0,14 & $0,55^{* *}$ & $0,46 * *$ \\
\hline
\end{tabular}




\section{International Journal of Current Science Research and Review}

ISSN: 2581-8341

Volume 04 Issue 08 August 2021

DOI: 10.47191/ijesrr/V4-i8-15, Impact Factor: 5.825

IJCSRR@ 2021

Www.ijcsrr.org

\begin{tabular}{llllllll}
\hline Fruit hardness & 0,07 & $0,36^{*}$ & 0,15 & 0,14 & 1 & $-0,01$ & 0,24 \\
Sugar content & 0,21 & 0,29 & $0,51^{* *}$ & $0,55^{* *}$ & $-0,01$ & 1 & 0,12 \\
Fruit diameter & 0,19 & 0,17 & 0,25 & $0,46^{* *}$ & 0,24 & 0,12 & 1 \\
\hline
\end{tabular}

Note: $*=$ correlated, $* *=$ highly correlated

Plant height, fruit number, fruit weight, and fruit hardness were all positively correlated with the number of branches. Taller plant increases number of branches, as a result, the number of fruits and their weight also increase. [24] reported that there was a relationship between the number of branches and fruit weight. The more branches, the higher the tomato fruit weight. The number of fruits positively correlated with plant height, branches, fruit weight, and sugar content. Thus, plant height, number of branches, and fruit weight influence the number of fruits produced. [25] reported that the number of fruits positively correlated with fruit weight, the more fruit, the higher the fruit weight. [26] also noted that the weight of the tomatoes increased with the number of fruits produced by the plant. Fruit weight positively correlated with plant height, branches, fruit number, sugar content, and fruit diameter. Thus, the plant height, branch number, fruit number, and fruit diameter determine tomatoes' weight. According to [27], all observed variables positively correlated with tomato fruit weight. The weight of the fruit increases as the number of fruits increases.

\section{CONCLUSIONS}

1. Applying Yellow Creeping Daisy compost 1-2 weeks before tomato planting provided a higher yield than at planting, as measured by fruit number, fruit diameter, and fruit weight per plant.

2. The application of a higher dose of Yellow Creeping Daisy compost increased tomato yield. Compost applied two weeks before planting at a 30 tons'/ha rate resulted in the highest tomato yield.

\section{REFERENCES}

1. Hardjowigeno, S. 2003. Ilmu Tanah. Akademi Presindo, Bogor, Indonesia.

2. Dharsini, M. K., Akalya, K., Ragul, P. S., Sathyaseelan, K., Narayanan, N., \& Kumar, D. S. 2020, November. Enhancement of soil properties using bottom ash, fly ash and coconut ash-An application of waste to wealth. In IOP Conference Series: Materials Science and Engineering. 955 (1): 012090). IOP Publishing.

3. Tittarelli, F., Petruzzelli, G., Pezzarossa, B., Civilini, M., Benedetti, A., and Sequi, P. 2007. Quality and Agronomic Use of Compost. In. Waste Management series 8. Diaz, Bertoldi, Bidlingmaier and Stentiford (editors). Elsevier Publishing.

4. Wright, A. L., Provin, T. L., Hons, F. M., Zuberer, D. A., and White, R. H. 2007. Compost source and rate effects on soil macronutrient availability under Saint Augustine Grass and Bermudagrass Turf. Compost Science and Utilization, 15(1): 22-28.

5. Muir, J. P., Butler, T., Helton, T. J., and McFarland, M. L. 2010. Dairy manure compost application rate and timing influence Bermudagrass yield and nutrient concentration. Crop Science, 50(5): 2133-2139.

6. Jouquet, E. P., Bloquel, E., Doan, T. T., Ricoy, M., Orange, D., Rumpel, C., and Duc, T. T. 2011. Do compost and vermicompost improve macronutrient retention and plant growth in degraded tropical soils?. Compost Science and Utilization, 19(1): 15-24.

7. D'Hose, T., Cougnon, M., De Vliegher, A., Willekens, K., Van Bockstaele, E., and Reheul, D. 2012. Farm compost application: effects on crop performance. Compost Science and Utilization, 20(1): 49-56.

8. Cummings, D. 2014. The Organic Composting Handbook. Skyhorse Publishing. New York.

9. Setyowati, N., Nurjanah, U., and Four, D.M. 2007. Singapore daisy (Wedelia trilobata L.) manure as inorganic nitrogen fertilizer subtitutiosn in pak choi (Brassica Chinensis L.) Proceeding of The $2^{\text {nd }}$ International Symposium on Food Security Agricultural Development and Environmental Conservation in Southeast and East Asia; Bogor, 4-6 September 2007

10. Andriani, M.R., Pujiwati, H., and Setyowati, N. 2021. The effects of compost sources and dosage on the growth and yield of edamame soybean (Glycine Max (L.) Merr) in Ultisol. Proceedings of the International Seminar on Promoting Local Resources for Sustainable Agriculture and Development (ISPLRSAD 2020), Advances in Biological Sciences Research, 13: 407- 412. https://www.atlantis-press.com/proceedings/isplrsad-20/articles 


\section{International Journal of Current Science Research and Review}

ISSN: 2581-8341

Volume 04 Issue 08 August 2021

DOI: 10.47191/ijesrr/V4-i8-15, Impact Factor: 5.825

IJCSRR @ 2021

WwW.ijcsrr.org

11. Setyowati, N., Muktamar, Z., Oktiasa, S., and Ganefianti, D.W. 2014. Growth and yield of chili pepper under different time application of wedelia (Wedelia triobata) and Siam weed (Chromolaena odorata) organic fertilizers. International Journal on Advance Science Engineering Information Technology (IJASEIT). 4(6): 13-16

12. Setyowati N, Nurjanah, U., and Korisma, R. 2009. Correlation between soil characteristics to production of red chili in substitution of $\mathrm{N}$-inorganic fertilizer with Yellow dot (Wedelia trilobata L.) bokashi. Akta Agrosia (12):184-194.

13. Setyowati N., Muktamar, Z., Suriyanti, B., and Simarmata, M. 2014. Growth and yield of chili pepper as affected by weed based organic compost and nitrogen fertilizer. International Journal on Advanced Science Engineering Information Technology 4(2):84-87.

14. Setyowati N, Nurjanah, U., Haryati, D. 2008. Wedelia (Wedelia trilobata) and Chromolaena (Chlomolaena odorata) as organic fertilizer on Pakchoi (Brasicca chinensis L.). Akta Agrosia (11):47-56.

15. Puspitasari, D. 2010. Phosphates Solubilizing Bacteria as Biofertilizer to the Grow and Production of Corn (Zea mays, L.). Undergraduate Thesis, Jurusan Biologi Fakultas Sains dan Teknologi Universitas Airlangga, Indonesia.

16. Nazirwan, A., Wahyudi, and Dulbari. 2014. Characterization of germplasm collection in local and introduction of tomato. J. Penelitian Pertanian Terapan. 14 (1):70-75

17. Rochani, A.T. 2001. Pengaruh Waktu Pemberian Azolla dan Dosis Pupuk P (Sp-36) terhadap Pertumbuhan dan Hasil Tanaman Padi (Oryza savita L.). Undergraduate Thesis. Fakultas Pertanian Universitas Brawijaya, Malang, Indonesia.

18. Surtinah. 2007. Kajian tentang hubungan pertumbuhan vegetatif dengan produksi tanaman tomat (Lycopersicum Esculentum, Mill). Jurnal Ilmiah Pertanian. 4(1):1-9

19. Utami, S. N. H. and Handayani, S. 2003. Chemicals properties in organic and conventional farming system. Ilmu Pertanian. $10(2): 63-69$

20. Kastono. D. 2005. Respon on growth and yield of black soybean in usage of organic fertilizer and biopesticide of Siam weed (Chromolaena odorata). J. Ilmu Pertanian. 12(02):103-116

21. Murniati, N. S., Setyono., and Sjarif. A. A. 2013. Analisis korelasi dan sidik lintas peubah pertumbuhan terhadap produksi cabai merah (Capsicum annuum L.). Jurnal Pertanian. 3(2):97-107

22. Amin, F., Adiwirman and Yuseva, S. 2015. Study on the application time of leguminous compost by bioactivator Trichoderma sp. toward the growth and production of chili (Capsicum annuum L). Jom Faperta. 2(1):1-15

23. Sjaifullah, 1996. Petunjuk Memilih Buah Segar. Penebar Swadaya, Jakarta.

24. Susi, N. 2006. Aplikasi pemberian beberapa dosis pos dan konsentrasi liquinox start terhadap pertumbuhan dan produksi tomat (Lycopersicum esculentum, Mill ), Jurnal Ilmiah Pertanian. 3 (1): 17 - 28.

25. Ganefianti, D. W., Pamekas, T., Alnopri and Hasanudin. 2006. Uji daya hasil pendahuluan galur-galur cabai hasil persilangan Talang Semut/Tit Super. Hasil Penelitian Hibah Bersaing. Fakultas Pertanian. Universitas Bengkulu, Bengkulu.

26. Sari, D. K. 2015. Pengaruh Dosis Vermikompos Terhadap Pertumbuhan dan Hasil Tanaman Tomat yang Dibudidayakan Secara Organik. Undergraduate Thesis. Universitas Bengkulu, Indonesia.

27. Febrianti, N. 2015.Respon Pertumbuhan dan Hasil Tanaman Tomat terhadap Berbagai Dosis Pupuk Kandang Sapi. Fakultas. Undergraduate Thesis. Fakultas Pertanian. Universitas Bengkulu, Bengkulu

Cite this Article: Nanik Setyowati, Zainal Muktamar, Eka Wiyanti (2021). Compost of Yellow Creeping Daisy (Wedelia Trilobata, L.) Weed to Increase Organic Tomato Yield. International Journal of Current Science Research and Review, 4(8), $983-990$ Corresponding Author Email: nsetyowati@unib.ac.id 